\title{
A Study on Implementing Internet Resources in Digitization of School Libraries
}

\author{
Hsiang-Yun Chen \\ Director of library
}

YuanLin Agriculture and Industrial Vocational High School

TAIWAN

In recent years people have seen a boom in the development of technology; therefore, Internet has been playing an increasingly important role in learning. The fastest developed information service system on the Internet is World Wide Web. WWW transmits all kinds of information via multimedia. Students would rather find information by surfing the net than do it by going to a library. Digital learning has become a tendency. Many school libraries have digitized their libraries. However, some libraries, especially those of elementary and high schools, do not have the budget to do so. Fortunately, many Internet resources are free. The purpose of this research is: if we can categorize useful Internet resources as we do with books, record the web addresses, give description of them in a clear web design page, and then put the web design page on the web site of the school library, we can offer them to the teachers and students who need these Internet resources. It not only complements the electronic collections of school libraries but also promotes the digitization of them.

\section{Introduction}

In recent years people have seen a boom in the development of technology; therefore, Internet has been playing an increasingly important role in learning .The fastest developed information service system on the Internet is World Wide Web (WWW). WWW transmits all kinds of information via multimedia (graph, word, sound, and so on). There has been an explosive increase in the number of site.

According to the result from Netcraft Web Server Survey (http://news.netcraft.com/archives/2007/02/index.html), they received responses from 110,460,149 sites in March 2007, an increase of 1.64 million from last month.

If we want to go online to search for some information, we simply need to key in the keywords on a search engine like Yahoo! ( http://www.yahoo.com ), Alta Vista Search Engine ( http://altavista.digital.com ), Excite , ( http://www.excite.com) etc , and then we can find lots of information about it. Some websites offer animations, colorful pictures, music, etc. 
Several people can use the search engine at the same time. On the contrary, if we want to find something in the library, maybe we need to browse through many books without much result, and sometimes the books we need happen to be borrowed. Consequently, students would rather find information by surfing the net than do it by going to a library.

Digital learning has become a tendency . Many school libraries provide computers for readers to search for what they want. Moreover, many school libraries become digitized to make it convenient for readers.

Under the impact of the era of computers, roles of school libraries should be changed into e-learning resource centers. For example, many school libraries have digitized their library collections. Yet, they need enough manpower to scan the contents of books into DVD. They also need enough budgets to buy databases and electronic books.

However, some libraries, especially those of elementary and high schools, do not have the budget to do so. Some libraries are so short of budget that their books only come from donation. Some libraries have only one librarian. It is impossible for them to change into e-learning resource centers.

Fortunately, many Internet resources are free. We can categorize them as we categorize books, record the web addresses of useful Internet resources, give description of them in the clear web design page, put the web design page on the web site of the school library, offer them to the teachers and students who need these Internet resources. It is good for students to search and integrate internet information.

\section{Merits derived from implementing Internet resources:}

There are five advantages of implementing useful Internet resources in the digitization of school libraries:

First, it complements the electronic collections of school libraries and promotes the digitization of them. For example, if a student asks about the stories of holidays, but there are no books of the same topic in the school library, then the librarian who knows the website about holidays can tell the reader how to find what he wants by implementing Internet resources. Collecting the websites of Internet resources which are suitable for students and putting them on the web page can serve more people directly.

Second, it solves the problem of the library without sufficient space and budget. We need many bookshelves to put a set of cyclopedia. But the space to put the cyclopedia can be 
saved if the contents of it can be found from Internet. The more Internet resources we have, the fewer bookshelves we need. There are many Internet resources which are free for use. Utilizing free Internet resources saves the budget for the purchase of books with similar contents to the free Internet resources.

Third, we can get more recent knowledge by implementing Internet resources. We can renew and complement knowledge at any moment. The newly printed books in school libraries can hardly keep up with the change of the times .For example, soon after the purchase of the guidebooks on Window95, Window98 is already on the market. There are new words which can't be found in the printed dictionary, while many online dictionaries offer new words. To check words online is more convenient and faster than to look up the dictionaries in the library.

Fourth, Internet resources can be implemented by different people at the same time. Since there are not many copies of the same book in the library, the book of the library may have been checked out when some reader wants to borrow it. If the contents of the book can be found on the Internet, the reader who can't borrow the book he wants can solve the problem. The readers can find information from Internet anytime.

Fifth, it can promote the cooperative relations between most school libraries by designing the web page to connect Internet resources. If we collect all Internet resources from different school libraries, it will be like numerous books in a virtual library.

\section{The methods of implementing Internet resources in the digitization of school libraries :}

The methods of implementing Internet resources in the digitization of school libraries are as follows :

1. Find useful Internet resources and put the names, web addresses, and brief descriptions about them on the design web page of school library. We can ask teachers of different subjects to offer web addresses of Internet resources suitable for the students. Teachers of different subjects can offer many Internet resources related to their professional knowledge.

2. There are many Internet resources that need categorizing. Some categorizations of Internet resources sorted by academic fields are not clear. It makes searching easier by classifying Internet resources with classification scheme for libraries and giving them numbers. We can use classifications like Dewey Decimal Classification, Library of Congress 
Classification, and New Classification Scheme for Chinese Libraries, etc. These classification schemes for libraries make searching easier because there are special academic fields meaning for different numbers.

3. The web page of recording Internet resources should be carefully designed so that it is easy to find the domain. It is better that the director has enough computer literacy to design the web address that can be easily found by keywords.

4. The director must know if the web address has been on the web page; for example the web address can be checked alphabetically. To avoid repetition of the web addresses, a specific person should be appointed to keep records.

5. The director should assign a number for each Internet resource like what we do with books. The director can categorize Internet resources with his/her professional knowledge. It is important that the director has been trained or owns related background of library.

6. Web addresses of the web page should be browsed regularly. It leaves the users negative impressions if he wants to browse a webpage and the computer monitor shows "The page cannot be found". The director must always check the web page to make sure that it still exists and let the users know that it is kept updated.

7. Not all resources are equally valuable or reliable. The chosen web page must be authoritative and accurate. Don't choose Internet resources with advertisements. We should choose a site created by an individual or an organization with authority or expertise. Internet resources of the government or academic organizations are more reliable.

8. Combine the work of many professional workers to offer the latest and best Internet resources. Establishing a committee to manage Internet resources in school is necessary. The members of the committee have to set up a policy of collecting Internet resources including criteria for selecting appropriate websites.

\section{Take the example of Yuanlin Agricultural and Industrial Vocational High School Internet resources web page:}

Take the example of my school library, Yuanlin Agricultural and Industrial Vocational High School library. The Internet resources web page

(http://www.ylvs.chc.edu.tw/administration/ylvs202/net.htm) is developed and categorized according to New Classification Schema for Chinese Libraries. I collect Internet 
resources myself and get more Internet resources from many other directors of high school libraries by E-mail. After arrangement, teachers and students of my school or other schools can use them by linking to the web page.

It makes me do the work because I usually browse Internet resources offered by some websites, but they usually offer the web addresses like government websites, train schedule websites, search engines, weather report websites, etc. They can be found in any search engine easily. "Why don't I offer some meaningful Internet resources?" I asked myself. I have started the work since 2005. Because these information from the web sites of the Internet resources web page is free, I introduce the web design page to everybody I meet on any occasion. When many people know it, they say "Why don't I know these meaningful and useful Internet resources earlier?"

Since the going on-line of the Internet resources web page, there have been things which deeply impressed me. Once there was a student of the Department of Horticulture, who wanted to find information about a kind of plant but there was no book about it in the library. I told him to try the site (http://plant.9s2u.com) which collects information of plants. He browsed the webpage and solved his problem. I once received an e-mail from a private museum worker, who asked me to record the web address of the museum. I browsed the webpage, found it suitable for students, and recorded it.

The Internet resources web page (http://www.ylvs.chc.edu.tw/administration/ylvs202/net.htm) of Yuanlin Agricultural and Industrial Vocational High School has recorded more than one hundred web sites. There are six parts about each web site.

1.Range number : According to New Classification Schema for Chinese Libraries , there are ten kinds of ranges as Table 1.

\section{【Table 1】}

\begin{tabular}{|l|l|l|l|l|l|}
\hline number & 0 & 1 & 2 & 3 & 4 \\
\hline range & Total & Philosophy & Religion & $\begin{array}{l}\text { Natural } \\
\text { Science }\end{array}$ & $\begin{array}{l}\text { Applied } \\
\text { Science }\end{array}$ \\
\hline number & 5 & 6 & 7 & 8 & 9 \\
\hline
\end{tabular}




\begin{tabular}{|l|l|l|l|l|l|}
\hline & Social & History \& \\
range & Science & $\begin{array}{l}\text { Geography of } \\
\text { China }\end{array}$ & $\begin{array}{l}\text { Geography of } \\
\text { the World }\end{array}$ & $\begin{array}{l}\text { Language \& } \\
\text { Literature }\end{array}$ & Art \\
\hline
\end{tabular}

2.Number in order : Each range is separated into ten parts. The front numeral is the part number of the range, and the back numeral is according to its recorded time.

3. Name: The name of the website.

4.Web address : The web address is not only showed in the web page but also linked to its site directly.

5.Explanation : It explains what does the web site include or its designer.

6.Recorded time : The recorded time helps browsers check more conveniently if he remembers the date he last browsed.

\section{Difficulties in maintaining the Internet resources web page and suggestions :}

There are some difficulties in maintaining the web page.

1. Manpower: Though many people tell me about new useful websites, I don't have enough time to record them .I can't often check whether they still exit or not. I hope that there are volunteers help me to maintain the web page.

2. Computer technique: I don't have enough computer background to make the webpage more friendly and vivid. For example, if someone wants to find Internet resource from the design web page he can't find by keying in a keyword but just by browsing the table to find what he want now.

3. Popularity: Many readers still don't know the useful webpage even though I told them in library education class.

4.Stability : If there is any trouble in connecting, the web page will be useless. It works only when we can surf the net. It is not as stable as looking up information in books of the library. 


\section{Conclusion}

Internet and WWW have become a major information and knowledge source for people. There are many search engines and we can key in the keywords to find the information we need. However, there are some Internet resources that cannot be found by keying in the keyword. Sometimes we key in the keyword and find many useless web pages, which take us much time to browse them. Designing web pages about linking Internet resources can save money and offer multiple faces of learning resources. Integrating Internet resource into learning is good for students. We can use the Internet as a very large knowledge base through the web page which is recorded many useful Internet resources.

\section{References}

1. March 2007 Web Server Survey. Retrieved March 19, 2007, from the World Wide Web: http://news.netcraft.com/archives/2007/02/index.html Total Sites Across All Domains August 1995 - March 2007

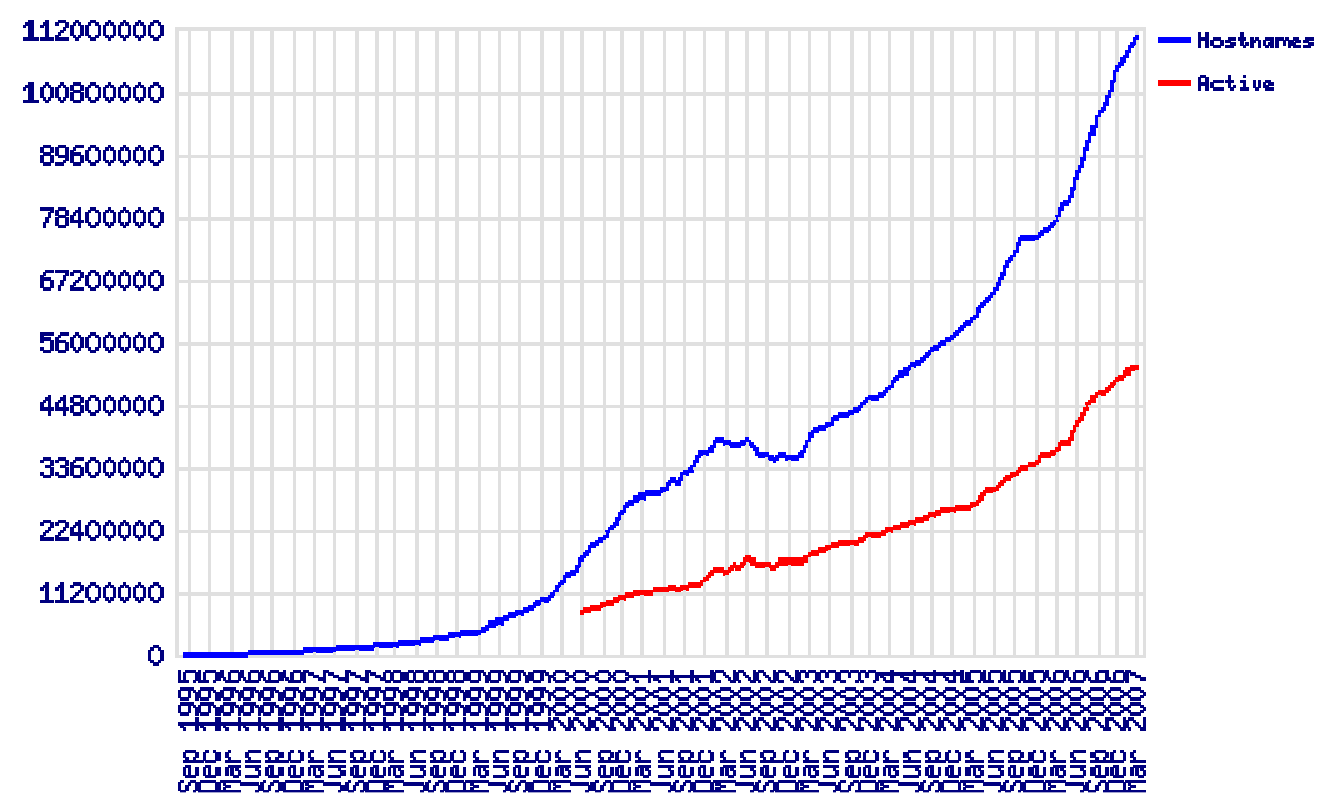

2. http://www.ylvs.chc.edu.tw/administration/ylvs202/net.htm

\begin{tabular}{|c|c|c|c|c|c|}
\hline 類別 & 編號 & 名稱 & 網址 & 說明 & 收錄日期 \\
\hline \multirow[t]{2}{*}{ 0 總類 } & $020-1$ & 國家圖書館 & http://www2.ncl.edu.tw/ & & \\
\hline & $020-2$ & -遠距圖書系 & http://www.read.com.tw/ & & \\
\hline
\end{tabular}




\begin{tabular}{|c|c|c|c|c|}
\hline & 統 & & & \\
\hline $020-3$ & $\begin{array}{l}\text { The Internet } \\
\text { Public } \\
\text { Library〈英〉 }\end{array}$ & http://www.ipl.org/ & |網路公共圖書館 & \\
\hline |020-4 & 維基文庫 & $\begin{array}{l}\text { http://zh. wikisource.org/w/index.php?title=首页 } \\
\underline{\text { \&variant=zh-tw }}\end{array}$ & $\begin{array}{l}\text { 免費文本內容的 } \\
\text { 圖書館,是一個由 } \\
\text { 志願者線上收集 } \\
\text { 自由內容 文本的 } \\
\text { 站點 }\end{array}$ & 2006/03/08 \\
\hline
\end{tabular}

3 Li-ping Chen, (2005). Electronic Resources and Library Collection Development

4. Calhoun, Karen \& Riemer, John J. (2001). CORC : new tools and possibilities for cooperative electronic resource description .New York : Haworth Information Press, c2001

\section{Author}

Chen ,Hsiang-Yun, library director of YuanLin Agriculture and Industrial Vocational Senior High School,Taiwan. There are 1,500 students in the school. There are more than 25,000 books in the school library. She has been the director of library for five years. She had library classes in National Sun Yat-Sen University for one year.She is also a Mathematic teacher. She has categorized Internet resources, recorded the web addresses and give description of them in the clear web design pages; put the web design pages( http://www.ylvs.chc.edu.tw/administration/ylvs202/net.htm )on the web site of the school library since 2005.

Address : No.313, Sec. 2, Yuanshui Rd., Yuanlin, Changhua County 510,Taiwan (R.O.C.)

Tel : 886-4-8360105ext202

Fax : 886-4-8363679

E-mail:che815@ylvs.chc.edu.tw 